\title{
Synthesis and physico-chemical studies of a novel noncentrosymmetric heptacoordinated cadmium(II) compound containing a tripodal amine, $\mathrm{CdCl}_{2}\left[\mathrm{~N}\left(\mathrm{C}_{2} \mathrm{H}_{6} \mathrm{~N}\right)_{3}\right]_{2}$
}

\author{
M. Ben Nasr ${ }^{a}$, K. Kaabi ${ }^{a}$, P. S. Pereira Silva ${ }^{b}$, F. Lefebvre ${ }^{c}$, C. Ben Nasr ${ }^{a^{*}}$ \\ aLaboratoire de Chimie des Matériaux, Faculté des Sciences de Bizerte, 7021 Zarzouna, Tunisie, \\ ${ }^{\mathrm{b}} \mathrm{CEMDRX}$, Department of Physics, University of Coimbra, P-3004-516 Coimbra, Portugal. \\ 'Laboratoire de Chimie Organométallique de Surface (LCOMS), Ecole Supérieure de Chimie Physique \\ Electronique, 69622 Villeurbanne Cedex, France.
}

*Corresponding author: cherif_bennasr@yahoo.fr

\begin{abstract}
A new noncentrosymmetric $\mathrm{Cd}(\mathrm{II})$ complex with thetripodal amine tris(2-aminoethyl)amine, $\mathrm{CdCl}_{2}\left[\mathrm{~N}_{(}\left(\mathrm{C}_{2} \mathrm{H}_{6} \mathrm{~N}\right)_{3}\right]_{2}$, has been prepared and characterized by single crystal X-ray diffraction, solid state NMR and IR spectroscopies. In the complex, the $\mathrm{Cd}(\mathrm{II})$ ion is surrounded by sevennitrogen atoms. The organic molecule acts as both a tri-and a tetradentate ligand. The cationic complexes are linked to each other forming layers parallel to the $(\mathrm{a}, \mathrm{b})$ plan. The $\mathrm{Cl}^{-}$counter ions occupy the cavities created inside these layers. The ${ }^{13} \mathrm{C}$ CP-MAS NMR spectra are in agreement with the X-ray structure. DFT calculations allow the attribution of the carbon peaks to the differentatoms. The vibrational absorption bands were identified by infrared spectroscopy and DFT calculations allowed their attributions.
\end{abstract}

\section{Indexing terms/Keywords}

X-ray diffraction; heptacoordinated cadmium complex; IR spectroscopy; CP-MAS NMR; DFT calculations.

\section{Council for Innovative Research}

Peer Review Research Publishing System

Journal: Journal of Advances in Chemistry

\author{
Vol. 10, No. 10 \\ editorjaconline@gmail.com
}

www.cirjac.com 


\section{INTRODUCTION}

Mono-, di- and polynuclear coordination compounds of cadmium(II) [1-6] are of great interest for the preparation of functional materials with specific electronic and optoelectronic properties [7, 8]. Recently, different cadmium(II) compounds with interesting molecular properties using multidentate $\mathrm{N}$-donor Schiff bases in combination with halides/pseudohalides were isolated [9-13]. The coordination behaviors of Schiff bases [14, 15] are of great interest because of their ease of preparation, structural variety, varied denticities and subtle steric and/or electronic effects leading to complexes of different dimensionalities. Halides [16-19] and pseudohalides [20-23] are suitable terminal/bridging units which in combination with organic ligands result in different mono-, di-, or polynuclear coordination molecules and supramolecular entities. Cadmium(II) with its $d^{10}$ configuration permits a wide range of symmetries and coordination numbers and reports on hexacoordinated cadmium(II) complexes are well documented [24-27]. However, heptacoordinated cadmium(II) complexes are scarce [28-30]. This work stems from our interest to build new molecular and crystalline architecture of cadmium(II) in combination with the tris(2-aminoethyl)amine as a Schiff base.

\section{Experiment}

\subsection{Chemical preparation}

An aqueous solution of $\mathrm{CdCl}_{2}(0.19 \mathrm{~g}, 1 \mathrm{mmol})$ in water $(10 \mathrm{~mL})$ was added dropwise to a solution of tris(2aminoethyl)amine $(0.29 \mathrm{~g}, 2 \mathrm{mmol}))$ in ethanol $(10 \mathrm{~mL})$. After stirring for $30 \mathrm{~min}$, the resultant mixture was evaporated at room temperature. Crystals of the title compound, which remained stable under normal conditions of temperature and humidity, were isolated after several days and subjected to X-ray diffraction analysis (yield $52 \%$ ).

\subsection{Investigation techniques}

\subsubsection{X-ray diffraction}

Single-crystal X-ray diffraction data were collected at room temperature on a Bruker APEX2 CCD area-detector diffractometer equipped with graphite-monochromatized MoKa radiation $(\lambda=0.71069 \AA)$. The structure was solved by direct methods using SHELXS-97 [31] and refinement was performed on $F^{2}$ by full-matrix least-squares techniques using SHELXL 2013 [32]. The non-hydrogen atoms were refined anisotropically, and hydrogen atoms isotropically. The drawings were made with Diamond [33]. The experimental conditions of data collection, the strategy followed for the structure determination and the final results are given in Table 1.

\subsubsection{Infrared spectroscopy}

The IR spectrum was recorded in the range $4000-400 \mathrm{~cm}^{-1}$ on a "Nicolet 6700 " spectrophotometer (resolution $=2$ $\mathrm{cm}^{-1}$, number of scans $=256$ ).

\subsubsection{DFT calculations}

The infrared spectrum and the ${ }^{13} \mathrm{C}$ NMR chemical shifts were calculated with the Gaussian 09 software. For this purpose a molecule containing one $\mathrm{Cd}$ atom surrounded by one tetracoordinated $\mathrm{N}\left(\mathrm{CH}_{2}-\mathrm{CH}_{2}-\mathrm{NH}_{2}\right)_{3}$ organic cation and three $\mathrm{N}-\mathrm{CH}_{2}-\mathrm{CH}_{2}-\mathrm{N}\left(\mathrm{CH}_{3}\right)_{2}$ groups mimicking the three cations linked by only one nitrogen was studied. All calculations were made with the B3LYP method. For all atoms the $6-31+G^{*}$ basis was chosen except for cadmium for which the LanL2DZ pseudopotential was used.In all cases the positions of the atoms were those determined by the X-ray diffraction study except for the hydrogen atoms which were first optimized at the above level of theory. Indeed the positions determined by X-ray do not correspond to the location of the proton but to that of the barycenter of charges. The ${ }^{13} \mathrm{C} N M R$ chemical shifts were then calculated by use of the GIAO method. The infrared spectrum was also calculated and the absence of imaginary frequencies was checked. 
Table 1. Experimental details of $\left[\mathrm{CdCl}_{2}\left(\mathrm{~N}\left(\mathrm{C}_{2} \mathrm{H}_{6} \mathrm{~N}\right)_{3}\right)_{2}\right]$.

\begin{tabular}{|c|c|}
\hline \multicolumn{2}{|l|}{ Crystal data } \\
\hline Chemical formula & $\mathrm{C}_{12} \mathrm{H}_{36} \mathrm{CdN}_{8} \cdot 2(\mathrm{Cl})$ \\
\hline$M_{r}$ & 475.79 \\
\hline Crystal system, space group & Trigonal, P31c \\
\hline Temperature (K) & 293 \\
\hline$a, c(\check{A})$ & $7.9706(2), 17.7771(7)$ \\
\hline$V\left(\AA^{3}\right)$ & $978.08(5)$ \\
\hline$Z$ & 2 \\
\hline Radiation type & Mo Ka \\
\hline$\mu\left(\mathrm{mm}^{-1}\right)$ & 1.40 \\
\hline Crystal size (mm) & $0.31 \times 0.27 \times 0.22$ \\
\hline \multicolumn{2}{|l|}{ Data collection } \\
\hline Diffractometer & BrukerAPEX2 CCD area-detector diffractometer \\
\hline Absorption correction & Multi-scan \\
\hline$T_{\min }, T_{\max }$ & $0.631,0.735$ \\
\hline $\begin{array}{l}\text { No. of measured, independent and } \\
\text { observed }[I>2 \sigma(I)] \text { reflections }\end{array}$ & $18683,1524,1517$ \\
\hline$R_{\text {int }}$ & 0.021 \\
\hline$(\sin \theta / \lambda)_{\max }\left(\AA^{-1}\right)$ & 0.651 \\
\hline \multicolumn{2}{|l|}{ Refinement } \\
\hline$R\left[F^{\dot{L}}>2 \sigma\left(F^{\dot{L}}\right)\right], w R\left(\digamma^{\dot{L}}\right), S$ & $0.023,0.063,1.12$ \\
\hline No. of reflections & 1524 \\
\hline No. of parameters & 70 \\
\hline No. of restraints & 1 \\
\hline$\Delta \rho_{\max }, \Delta \rho_{\min }\left(\mathrm{e} \AA^{-3}\right)$ & $0.30,-0.57$ \\
\hline
\end{tabular}

\section{Results and discussion}

\subsection{Structure description}

The ortep view of the title noncentrosymmetric coordination compound, $\left.\mathrm{CdCl}_{2}\left[\mathrm{~N}_{(} \mathrm{C}_{2} \mathrm{H}_{6} \mathrm{~N}\right)_{3}\right]_{2}$ (Fig. 1), shows that the crystal structure contains four cristallographically independent nitrogen atoms. The N1, N2 and N4 atoms are coordinated to cadmium, while N3 is not coordinated. In the atomic arrangement, the distorted polyhedral Cd environment contains seven nitrogen atoms (Fig. 2) belonging to two independent ligands. The first ligand, having N3 as central nitrogen atom, is tricoordinated to the $\mathrm{Cd}(\mathrm{II})$ cation via $\mathrm{N} 4, \mathrm{~N} 4^{\mathrm{i}}$ and $\mathrm{N} 4^{\mathrm{ii}}$ terminal nitrogen atoms (for symmetry code, see Table 2). The second ligand, containing the central nitrogen atom N1, is tetracoordinated to the cadmium atom via its four nitrogen atoms $\mathrm{N} 1, \mathrm{~N} 2, \mathrm{~N} 2{ }^{\mathrm{i}}$ and $\mathrm{N} 2^{\mathrm{ii}}$, (for symmetry code, see Table 2). Table 3 shows that the atoms $\mathrm{Cd}, \mathrm{N} 1, \mathrm{~N} 3, \mathrm{Cl} 1$ and $\mathrm{Cl} 2$ are located on special positions. In the atomic arrangement, the polyhedra are interconnected via the first ligand forming layers parallel to the (a, b) plane (Fig. 3). 
Table 2. Selected bond distances and angles $\left(\stackrel{\AA}{\AA}, \stackrel{\circ}{)}\right.$ in $\left[\mathrm{CdCl}_{2}\left(\mathrm{~N}_{(}\left(\mathrm{C}_{2} \mathrm{H}_{6} \mathrm{~N}\right)_{3}\right)_{2}\right]$.

\begin{tabular}{|c|c|c|c|}
\hline $\mathrm{Cd} 1-\mathrm{N} 2$ & $2.429(3)$ & $\mathrm{Cd} 1-\mathrm{N} 4$ & $2.496(3)$ \\
\hline $\mathrm{Cd} 1-\mathrm{N} 2^{\prime}$ & $2.429(3)$ & $\mathrm{Cd} 1-\mathrm{N} 4^{\prime}$ & $2.496(2)$ \\
\hline $\mathrm{Cd} 1-\mathrm{N} 2 "$ & $2.429(3)$ & $\mathrm{Cd} 1-\mathrm{N} 1$ & $2.684(4)$ \\
\hline $\mathrm{Cd} 1-\mathrm{N} 4^{\prime \prime}$ & $2.496(2)$ & $\mathrm{N} 2-\mathrm{Cd} 1-\mathrm{N} 4$ & $79.70(10)$ \\
\hline $\mathrm{N} 2-\mathrm{Cd} 1-\mathrm{N} 2^{1}$ & $107.53(7)$ & $\mathrm{N} 2{ }^{\prime}-\mathrm{Cd} 1-\mathrm{N} 4^{\prime}$ & $166.75(9)$ \\
\hline $\mathrm{N} 2-\mathrm{Cd} 1-\mathrm{N} 2^{\prime \prime}$ & $107.53(7)$ & $\mathrm{N} 2^{\prime \prime}-\mathrm{Cd} 1-\mathrm{N} 4^{\prime}$ & $79.97(9)$ \\
\hline $\mathrm{N} 2^{\prime}-\mathrm{Cd} 1-\mathrm{N} 2^{\prime \prime}$ & $107.53(7)$ & $\mathrm{N} 4{ }^{\prime \prime}-\mathrm{Cd} 1-\mathrm{N} 4^{\prime}$ & $90.93(10)$ \\
\hline $\mathrm{N} 2-\mathrm{Cd} 1-\mathrm{N} 4 "$ & $79.97(9)$ & $\mathrm{N} 4-\mathrm{Cd} 1-\mathrm{N} 4$ & $90.93(10)$ \\
\hline $\mathrm{N} 2-\mathrm{Cd} 1-\mathrm{N} 4^{\prime \prime}$ & $79.70(10)$ & $\mathrm{N} 2-\mathrm{Cd} 1-\mathrm{N} 1$ & $68.65(7)$ \\
\hline $\mathrm{N} 2^{\prime \prime}-\mathrm{Cd} 1-\mathrm{N} 4^{\prime \prime}$ & $166.75(9)$ & $\mathrm{N} 2{ }^{\prime}-\mathrm{Cd} 1-\mathrm{N} 1$ & $68.65(7)$ \\
\hline $\mathrm{N} 2-\mathrm{Cd} 1-\mathrm{N} 4$ & $166.75(9)$ & $\mathrm{N} 2 "-\mathrm{Cd} 1-\mathrm{N} 1$ & $68.65(7)$ \\
\hline $\mathrm{N} 2-\mathrm{Cd} 1-\mathrm{N} 4$ & $79.97(9)$ & $\mathrm{N} 4 "-\mathrm{Cd} 1-\mathrm{N} 1$ & $124.60(7)$ \\
\hline $\mathrm{N} 2 "-\mathrm{Cd} 1-\mathrm{N} 4$ & $79.70(10)$ & $\mathrm{N} 4-\mathrm{Cd} 1-\mathrm{N} 1$ & $124.60(7)$ \\
\hline $\mathrm{N} 4 "-\mathrm{Cd} 1-\mathrm{N} 4$ & $90.93(10)$ & $\mathrm{N} 4{ }^{\prime}-\mathrm{Cd} 1-\mathrm{N} 1$ & $124.60(7)$ \\
\hline
\end{tabular}

Symmetry codes: (i) $-x+y,-x+1, z$; (ii) $-y+1, x-y+1, z$; (iii) $-x+y+1,-x+2, z$; (iv) $-y+2, x-y+1, z$.

Table 3. Fractional atomic coordinates and isotropic or equivalent isotropic displacement parameters $\left(\AA^{2}\right)$.

\begin{tabular}{|l|l|l|l|l|}
\hline & $x$ & $y$ & $z$ & $U_{\text {iso }}^{*} / U_{\text {eq }}$ \\
\hline Cd1 & 0.3333 & 0.6667 & $0.100296(13)$ & $0.02455(10)$ \\
\hline N1 & 0.3333 & 0.6667 & $-0.0507(2)$ & $0.0232(8)$ \\
\hline N2 & $0.0157(4)$ & $0.4376(4)$ & $0.05054(16)$ & $0.0359(5)$ \\
\hline H2A & 0.1138 & 0.4226 & 0.0586 & $0.043^{*}$ \\
\hline H2B & -0.0634 & 0.4205 & 0.0865 & $0.043^{*}$ \\
\hline N3 & 1.0000 & 1.0000 & $0.2733(2)$ & $0.0225(7)$ \\
\hline N4 & $0.6220(4)$ & $0.8739(4)$ & $0.18003(16)$ & $0.0349(5)$ \\
\hline H4A & 0.6997 & 0.9919 & 0.1670 & $0.042^{*}$ \\
\hline H4B & 0.5317 & 0.7969 & 0.1499 & $0.042^{*}$ \\
\hline C1 & $0.1424(4)$ & $0.5127(4)$ & $-0.07617(17)$ & $0.0300(6)$ \\
\hline H1A & 0.1419 & 0.3909 & -0.0784 & $0.036^{*}$ \\
\hline H1B & 0.1176 & 0.5426 & -0.1264 & $0.036^{*}$ \\
\hline C2 & $-0.0162(4)$ & $0.4921(4)$ & $-0.02389(18)$ & $0.0349(7)$ \\
\hline H2C & -0.0160 & 0.6138 & -0.0211 & $0.042^{*}$ \\
\hline H2D & -0.1413 & 0.3938 & -0.0429 & $0.042^{*}$ \\
\hline C3 & $0.8086(4)$ & $0.9562(4)$ & $0.30021(16)$ & $0.0271(5)$ \\
\hline H3A & 0.8016 & 1.0742 & 0.2997 & $0.033^{*}$ \\
\hline
\end{tabular}




\begin{tabular}{l|l|l|l|l|}
\hline H3B & 0.7931 & 0.9117 & 0.3519 & $0.033^{\star}$ \\
\hline C4 & $0.6434(4)$ & $0.8040(5)$ & $0.2537(2)$ & $0.0326(6)$ \\
\hline H4C & 0.6642 & 0.6951 & 0.2463 & $0.039^{\star}$ \\
\hline H4D & 0.5237 & 0.7575 & 0.2816 & $0.039^{\star}$ \\
\hline Cl1 & 0.6667 & 1.3333 & $0.19100(9)$ & $0.0362(3)$ \\
\hline Cl2 & 0.0000 & 1.0000 & $0.03650(10)$ & $0.0438(3)$ \\
\hline
\end{tabular}

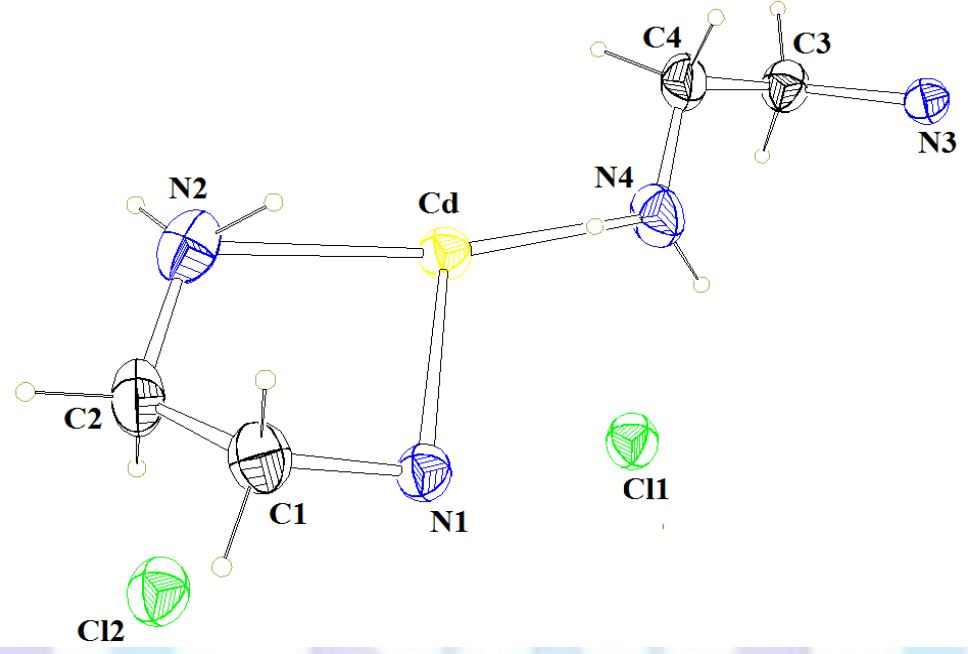

Figure 1. View of the local coordination of the $\mathrm{Cd}(\mathrm{II})$ cations in $\mathrm{CdCl}_{2}\left[\mathrm{~N}_{(}\left(\mathrm{C}_{2} \mathrm{H}_{6} \mathrm{~N}\right)_{3}\right]_{2}$ showing the atom-numbering scheme. Displacement ellipsoids are drawn at the $50 \%$ probability level.

Inside each layer, the $\mathrm{Cl}^{-}$counter ions occupy the created cavities and connect the metal complexes by a set of $\mathrm{N}-\mathrm{H} \ldots \mathrm{Cl}$ hydrogen bonds (Fig. 4, Table 4). It is worth noticing that the hydrogen atoms $(\mathrm{H} 1 \mathrm{~A}$ and $\mathrm{H} 1 \mathrm{~B})$, linked to the N1 nitrogen atom, and the $\mathrm{Cl} 2$ chlorine atom are not involved in hydrogen bondings (Table 4) while all hydrogen atoms attached to the N2 and N4 nitrogen atoms are hydrogen bonded to Cl1 chlorine atoms.

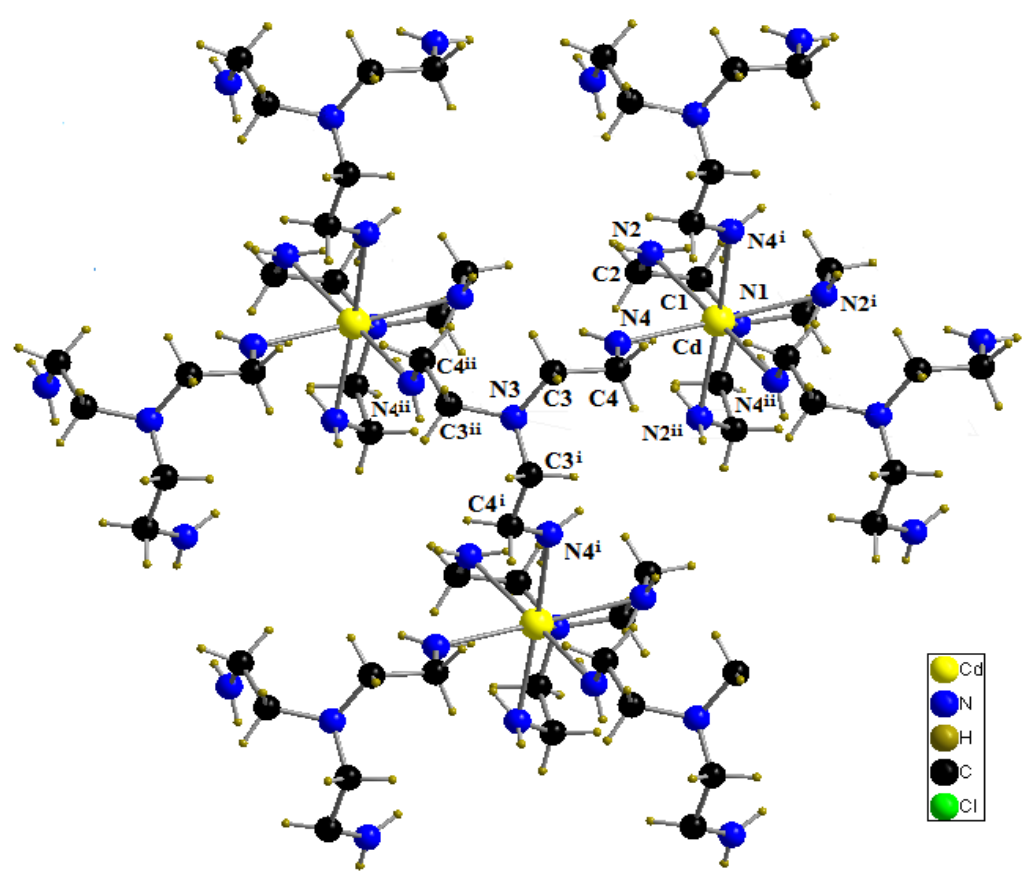

Figure 2. Coordination environment of the $\mathrm{Cd}(\mathrm{II})$ atom with atomic labels in $\mathrm{CdCl}_{2}\left[\mathrm{~N}\left(\mathrm{C}_{2} \mathrm{H}_{6} \mathrm{~N}\right)_{3}\right]_{2}$. 
Table 4. Hydrogen-bond geometry $\left(\AA \stackrel{\AA}{9}, \stackrel{9}{)}\right.$ in $\left[\mathrm{CdCl}_{2}\left(\mathrm{~N}\left(\mathrm{C}_{2} \mathrm{H}_{6} \mathrm{~N}\right)_{3}\right)_{2}\right]$.

\begin{tabular}{lllll}
\hline$D-\mathrm{H} \cdots A$ & $D-\mathrm{H}$ & $\mathrm{H} \cdots A$ & $D \cdots A$ & $D-\mathrm{H} \cdots A$ \\
\hline $\mathrm{N} 2-\mathrm{H} 2 A \cdots \mathrm{N} 4$ & 0.86 & 2.53 & $3.157(4)$ & 131 \\
\hline $\mathrm{N} 2-\mathrm{H} 2 B \cdots \mathrm{Cl}{ }^{\mathrm{v}}$ & 0.86 & 2.66 & $3.515(3)$ & 174 \\
\hline $\mathrm{N} 4-\mathrm{H} 4 A \cdots \mathrm{Cl} 1$ & 0.86 & 2.89 & $3.503(3)$ & 129 \\
\hline $\mathrm{N} 4-\mathrm{H} 4 B \cdots \mathrm{N}{ }^{\prime \prime}$ & 0.86 & 2.58 & $3.157(4)$ & 126 \\
\hline
\end{tabular}

Symmetry codes: (i) $-x+y,-x+1, z$; (ii) $-y+1, x-y+1, z ;(v) x-1, y-1, z$.

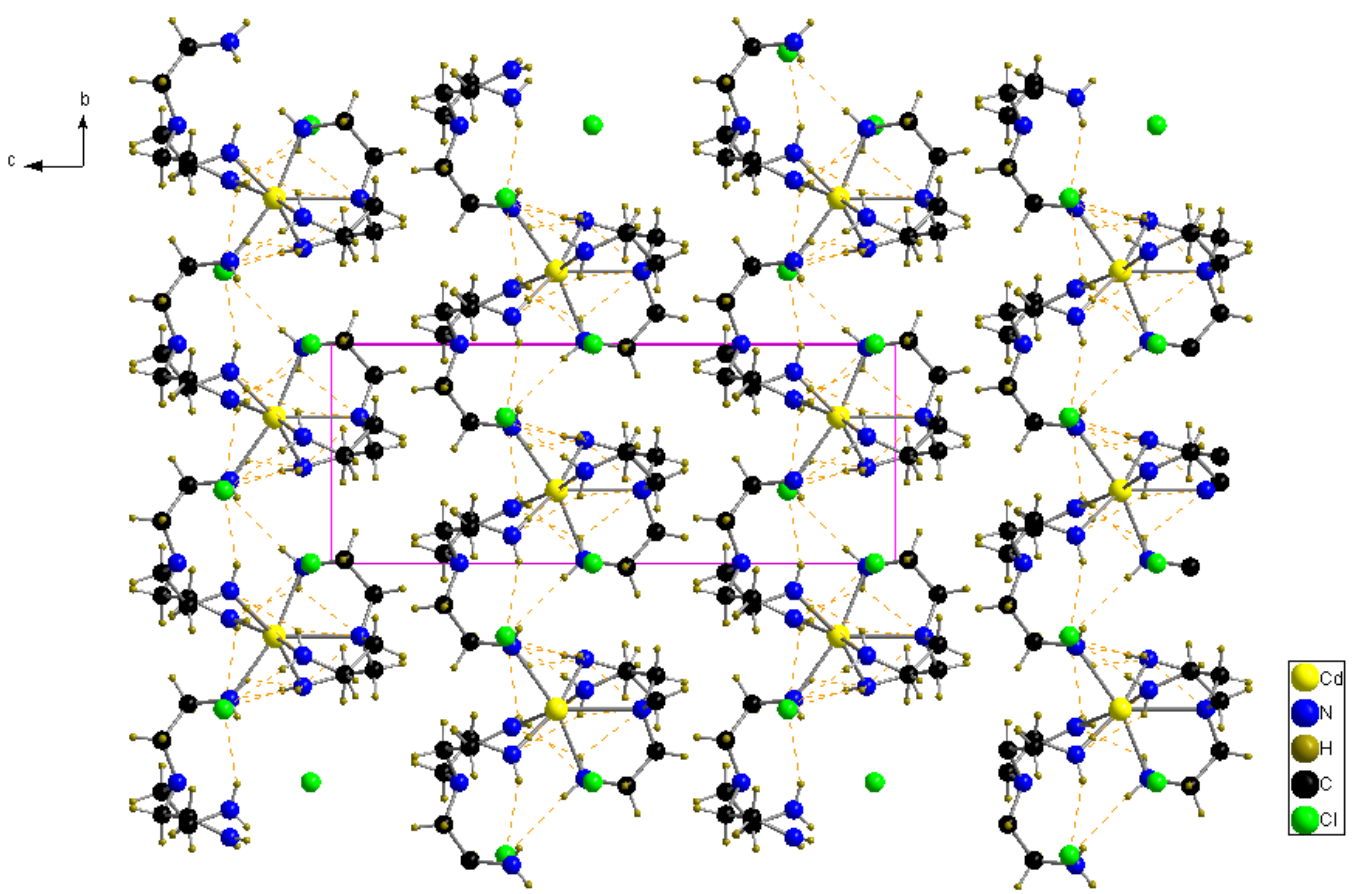

Figure 3. View of $\mathrm{CdCl}_{2}\left[\mathrm{~N}\left(\mathrm{C}_{2} \mathrm{H}_{6} \mathrm{~N}\right)_{3}\right]_{2}$ along the a axis. The dotted lines indicate hydrogen bonds.

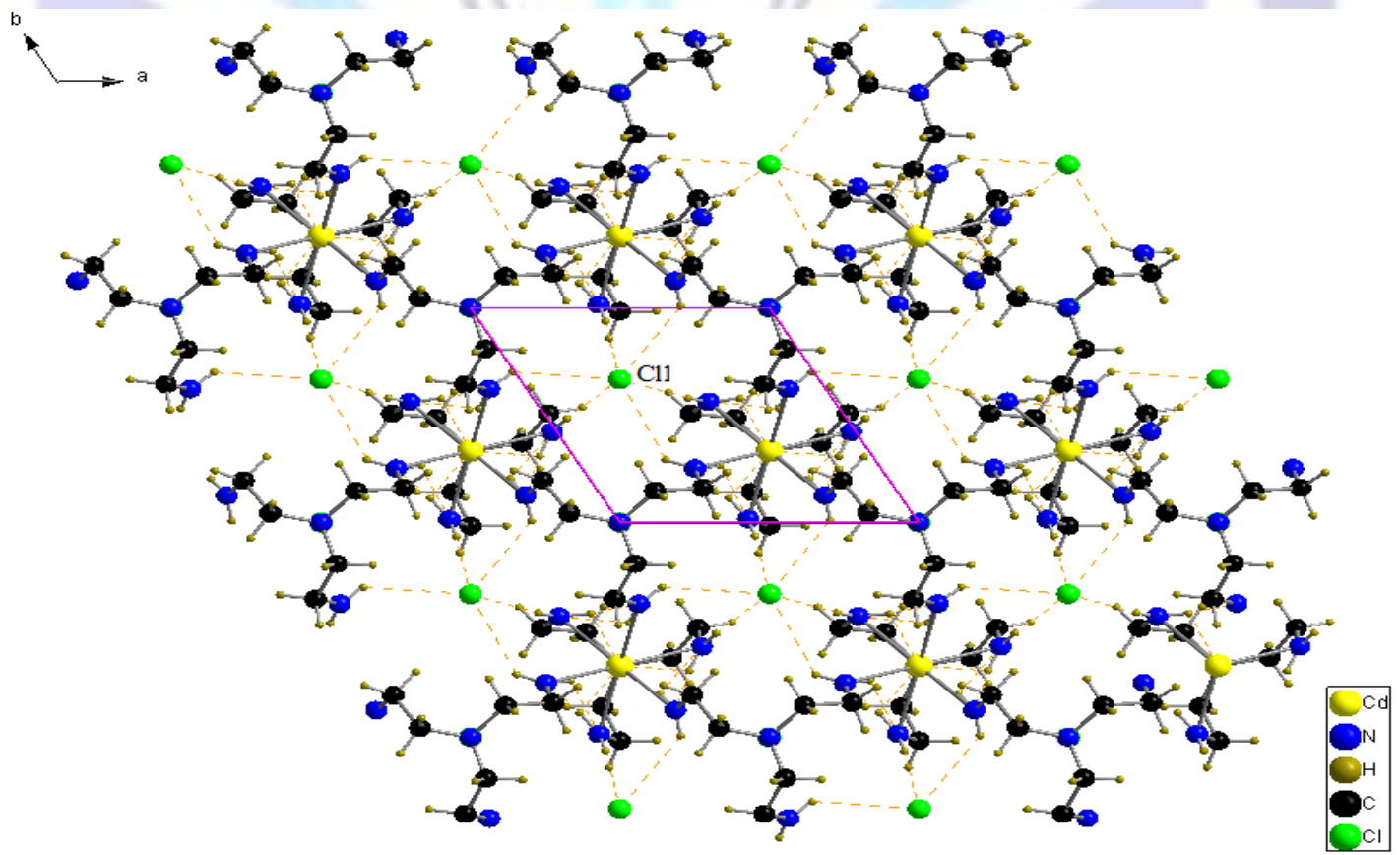

Figure 4. View of a layer in $\mathrm{CdCl}_{2}\left[\mathrm{~N}\left(\mathrm{C}_{2} \mathrm{H}_{6} \mathrm{~N}\right)_{3}\right]_{2}$. The dotted lines indicate hydrogen bonds. 


\subsection{NMR results}

The ${ }^{13} \mathrm{C}$ CP-MAS NMR spectrum of $\mathrm{CdCl}_{2}\left[\mathrm{~N}\left(\mathrm{C}_{2} \mathrm{H}_{6} \mathrm{~N}\right)_{3}\right]_{2}$ is shown in Fig. 5. It exhibits four broad and asymmetric resonances corresponding to the four crystallographically independent carbon atoms. The observed asymmetry and broadening of the lines are caused by the ${ }^{13} \mathrm{C}-{ }^{14} \mathrm{~N}$ dipolar coupling perturbed by the ${ }^{14} \mathrm{~N}$ quadrupole interaction. This phenomenon is usually observed in the ${ }^{13} \mathrm{C}$ spectra of carbon atoms bonded to nitrogen atoms in organic compounds [34].

Theoretical calculations were undertaken in order to assign the NMR resonances to the different crystallographically independent carbon atoms of the unit cell. The theoretical chemical shifts were subtracted from those of the reference (tetramethylsilane)calculated at the same level of theory. The results are listed on Table 5 and show a very good agreement between theory and experiment.

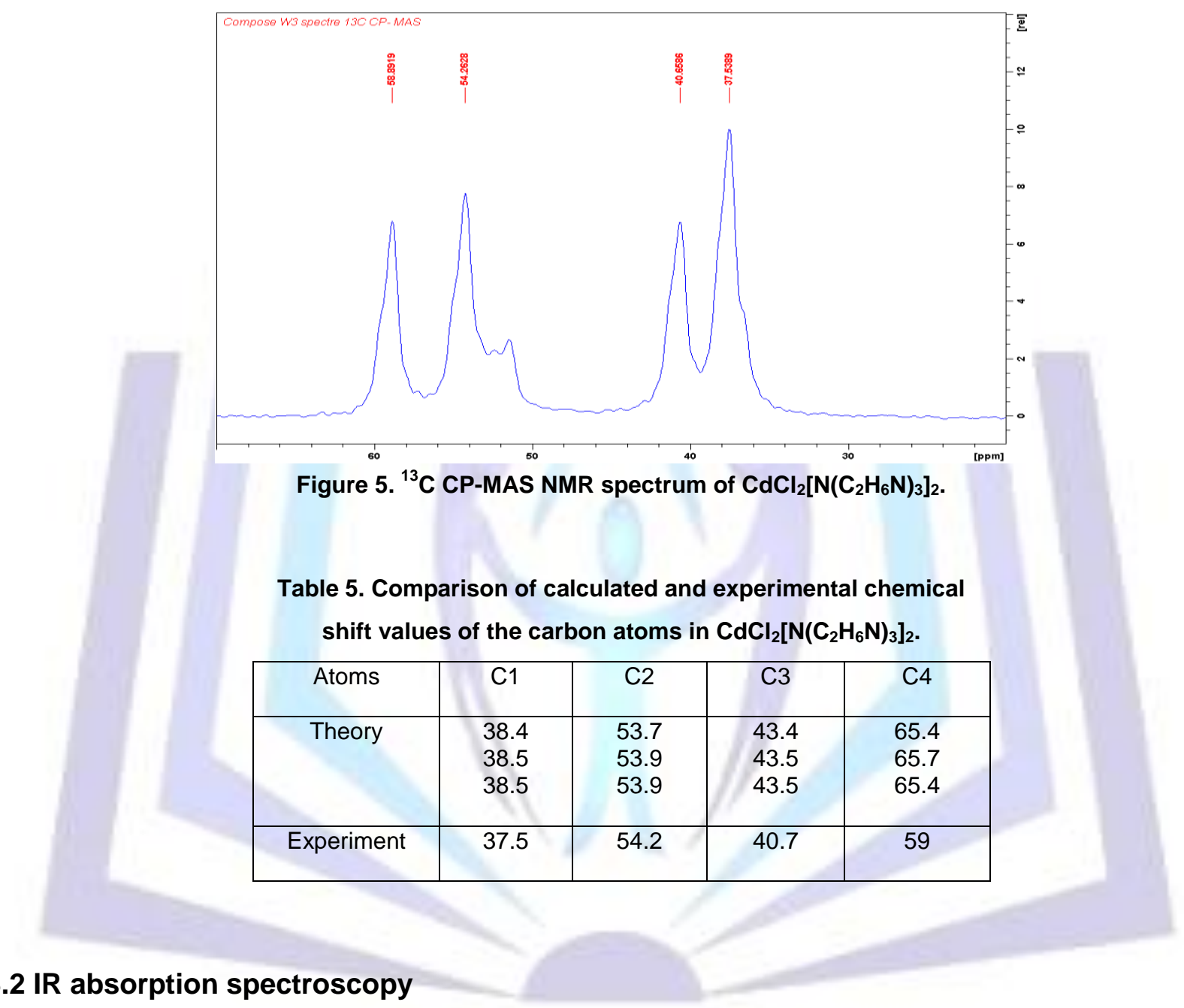

FTIR spectroscopy was used to verify the functional groups present in the crystal and their vibrational behavior in the solid state. Hydrogen bonding interactions are able to affect both frequency as well as intensity and width of the vibrations. The IR spectrum of crystalline $\mathrm{CdCl}_{2}\left[\mathrm{~N}\left(\mathrm{C}_{2} \mathrm{H}_{6} \mathrm{~N}\right)_{3}\right]_{2}$ is shown in Figure 6 . The characteristic vibrational modes of the compound can be compared to those of similar materials [35-37]. In the high-frequency region, the stretching vibrations of the amino groups can be found. Hydrogen bonding interactions are able to affect frequency as well as intensity and width of these vibrations. The bands observed at $\left(3442-3154 \mathrm{~cm}^{-1}\right)$ can be assigned to the asymmetric and symmetric stretching modes of the $\mathrm{NH}_{2}$ group, respectively. The bands between 2963 and $2807 \mathrm{~cm}^{-1} \mathrm{can}_{\text {be attributed to }}$ the stretching vibrations of the $\mathrm{CH}_{2}$ alkyl groups [38]. The adjacent carbon atoms attached to the $\mathrm{CH}_{2}$ groups were also involved in the wagging, twisting and rocking modes of these groups. This induces a coupling between the adjacent $\mathrm{CH}_{2}$ groups. The bands observed at $\left(1400-1317 \mathrm{~cm}^{-1}\right)$ can thus be assigned to wagging modes and those observed at (1287$1107 \mathrm{~cm}^{-1}$ ) to the $\mathrm{CH}_{2}$ twisting modes and to the $\mathrm{C}-\mathrm{N}$ and $\mathrm{C}-\mathrm{C}$ stretching vibrations. Finally, those observed at 1065-743 $\mathrm{cm}^{-1}$ correspond to the $\mathrm{CH}_{2}$ rocking modes [39]. 


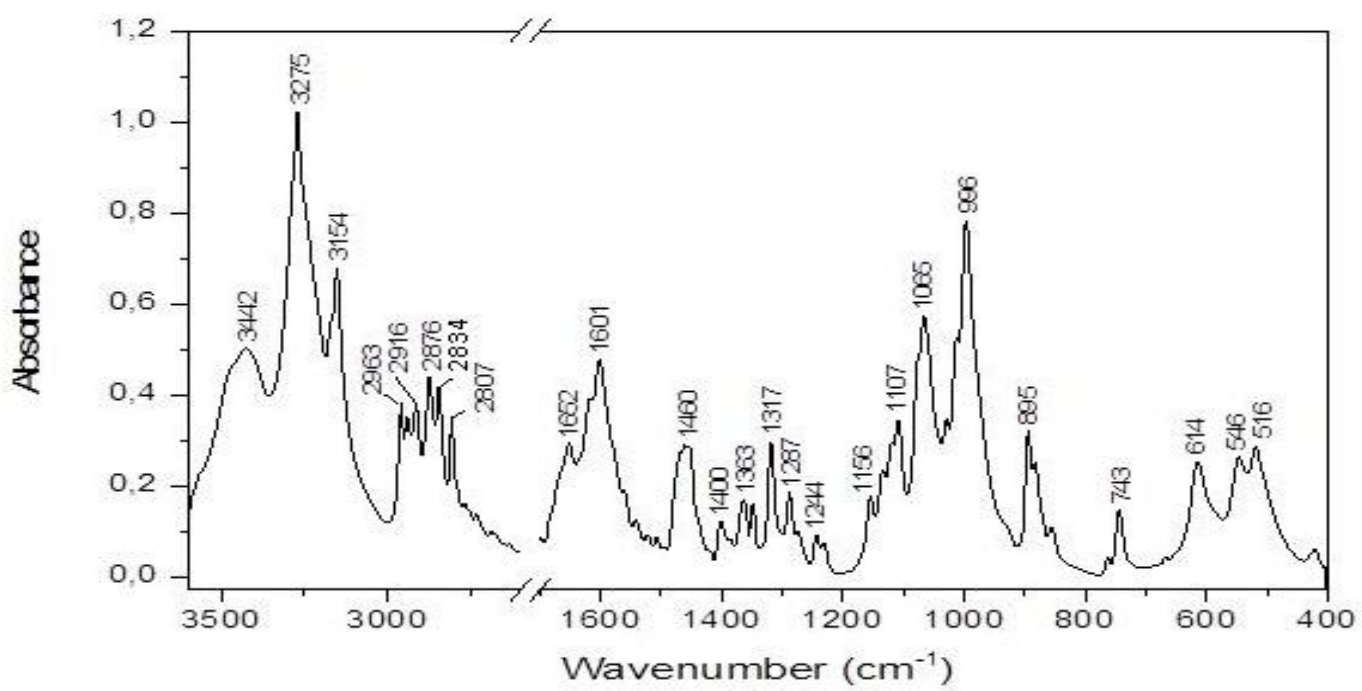

Figure 6. Infrared absorption spectrum of $\mathrm{CdCl}_{2}\left[\mathrm{~N}\left(\mathrm{C}_{2} \mathrm{H}_{6} \mathrm{~N}\right)_{3}\right]_{2}$.

DFT calculations showed that the inorganic entities lead to vibrations below $500 \mathrm{~cm}^{-1}$ which are not observed experimentally in our conditions. So we focused only on the vibrations of the organic cation. X-ray diffraction data give C$\mathrm{H}$ or $\mathrm{N}-\mathrm{H}$ distances which are too small compared to what is usually observed (typically below $0.1 \mathrm{~nm}$ ) due to the fact that this method is not sensitive to the nuclei but to the electrons and so gives values corresponding to distances between the barycenters of electronic charges. As a consequence the positions of protons were first optimized, the $\mathrm{Cd}, \mathrm{C}$ and $\mathrm{N}$ atoms being located at the positions given by the $\mathrm{X}$-ray study. The resulting $\mathrm{C}-\mathrm{H}$ and $\mathrm{N}-\mathrm{H}$ distances corresponded to what is usually obtained (typically $0.109 \mathrm{~nm}$ for $\mathrm{C}-\mathrm{H}$ and $0.104 \mathrm{~nm}$ for $\mathrm{N}-\mathrm{H}$ ) and the frequencies calculation was made on the semi-optimized geometry. The resulting IR spectra, calculated by the same method than the NMR chemical shifts, are shown on Figure 7 and is very similar to the experimental spectrum allowing a good correlation between the experimental and theoretical data as shown on Figure 8. Thus, the precision is well-sufficient to assign the experimental frequencies and to confirm the attributions proposed above.

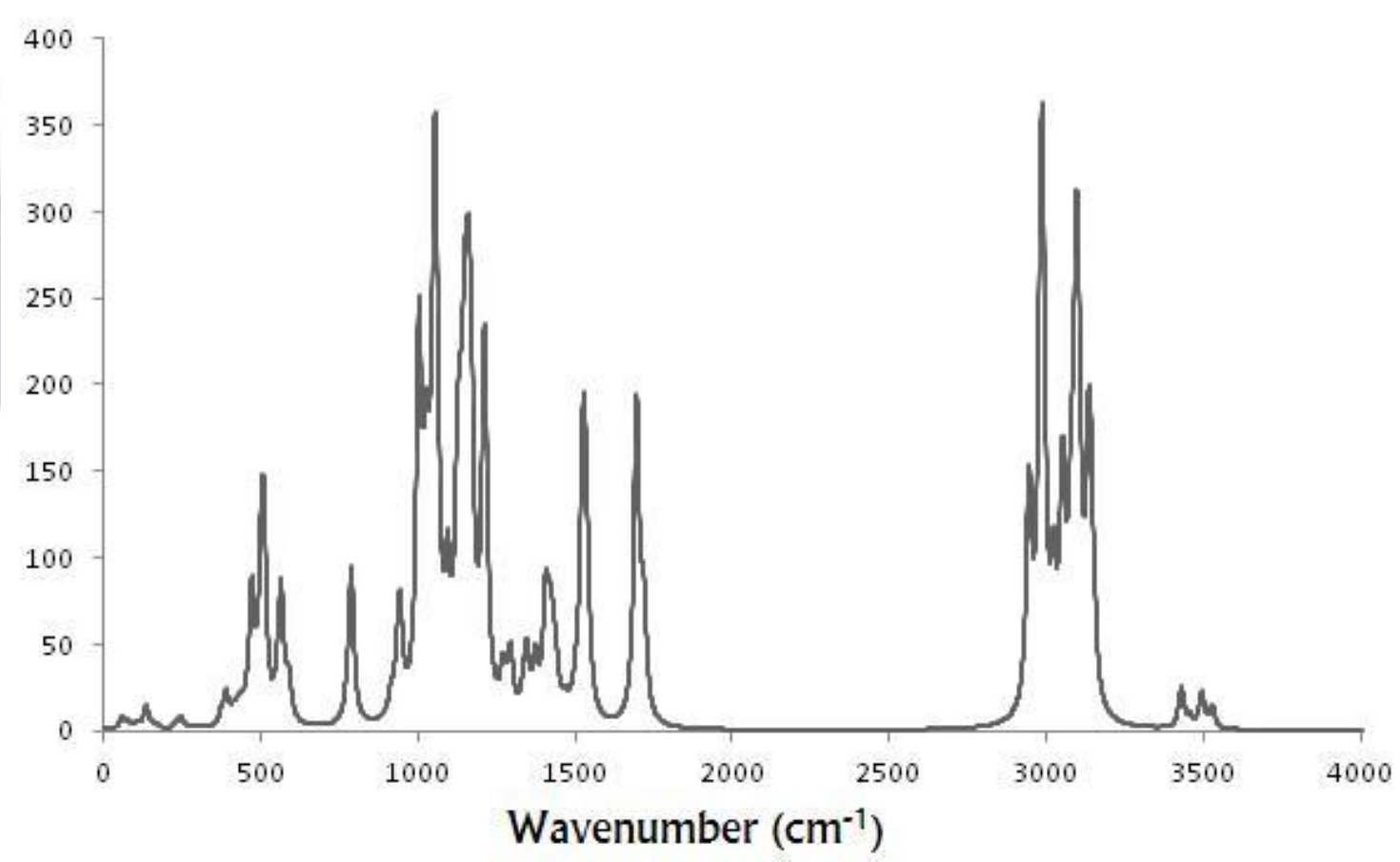

Figure 7. Calculated IR absorption spectrum of $\mathrm{CdCl}_{2}\left[\mathrm{~N}\left(\mathrm{C}_{2} \mathrm{H}_{6} \mathrm{~N}\right)_{3}\right]_{2}$. 


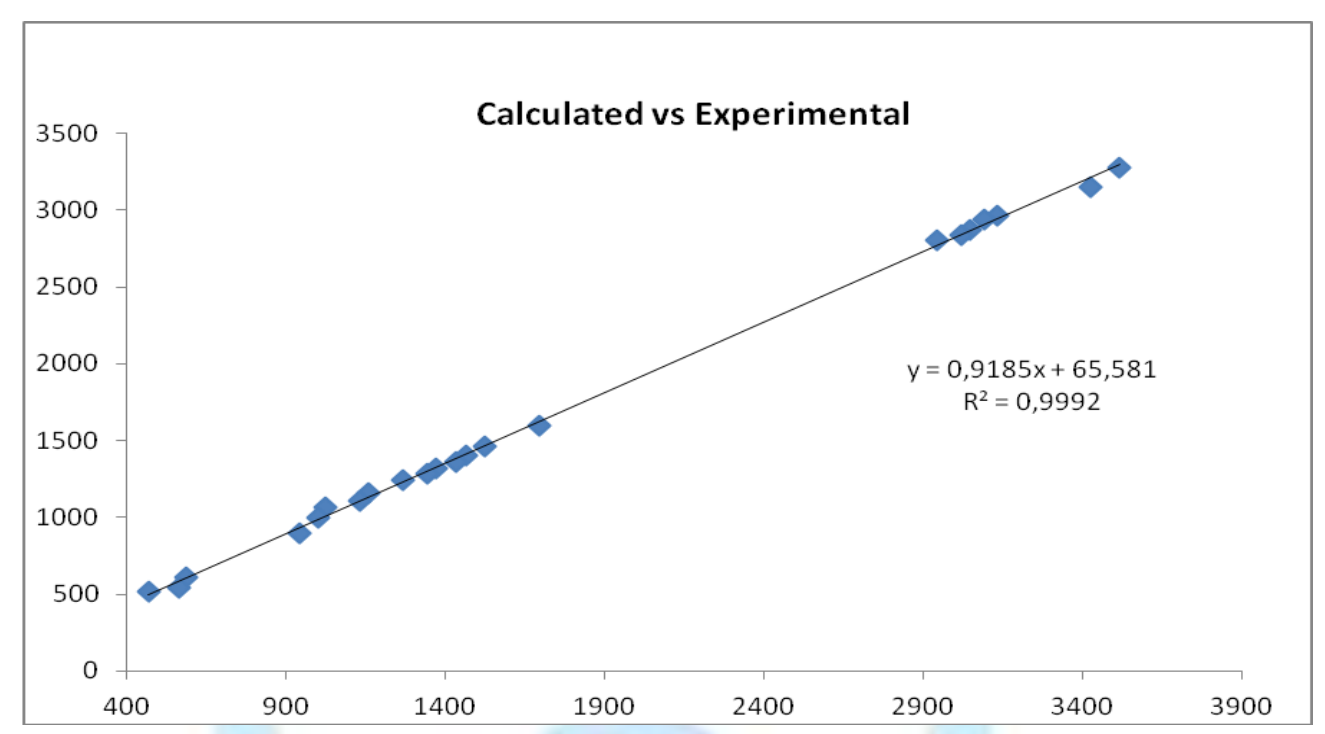

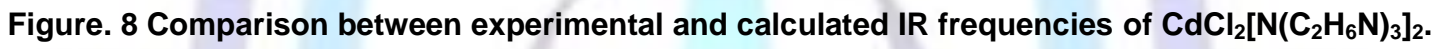

\section{Conclusions}

In the crystal structure of the complex, the $\mathrm{Cd}(\mathrm{II})$ ionis heptacoordinated to seven nitrogen atoms belonging to two cristallographically independent tris(2-aminoethyl)amine ligands. One of them acts as a tetradentalewhile the other is a tridentateligand. The cationic complexes are linked to each other forming layers parallel to the $(\mathrm{a}, \mathrm{b})$ plane. The $\mathrm{Cl}^{-} \mathrm{counter}$ ions occupy the cavities created inside these layers. The crystal packing is stabilized by $\mathrm{N}-\mathrm{H}$...N and $\mathrm{N}-\mathrm{H}$... Cl hydrogen bonds. The vibrational properties of this structure were studied by infrared spectroscopy. The number of ${ }^{13} \mathrm{C}$ CP-MAS NMR lines is in full agreement with the crystallographic data.

\section{Acknowledgements}

We would like to acknowledge the support provided by the Secretary of State for Scientific Research and Technology of Tunisia.

\section{Supplementary data}

CCDC 1034564 contains the supplementary crystallographic data for the title complex. These data can be obtained free of charge from the Cambridge Crystallographic Data Centre via http://www.ccdc.cam.ac.uk/conts/retrieving.html, or from the CCDC, 12Union Road, Cambridge, CB2 1EZ, UK: fax: (+44) 01223-336-033; e-mail: deposit@ccdc.cam.ac.

\section{References}

[1] H. Zhang, X. Wang, K. Zhang, B.K. Teo, Coord. Chem. Rev. 183 (1999) 157.

[2] Q.-G. Zhai, X.-Y.Wu, S.-M.Chen, C.-Z.Lu, W.-B.Yang, Cryst.Growth Des. 6(2006) 2126.

[3] H. Deng, Y.-C.Qiu, Y.-H.Li, Z.-H.Liu, R.-H.Zeng, M. Zeller, S.R. Batten, Chem.Commun.(2008) 2239.

[4] P. Cui, Z. Chen, D. Gao, B. Zhao, W. Shi, P. Cheng, Cryst. Growth Des.10 (2010) 4370.

[5] J. Yang, B. Wu, F. Zhuge, J. Liang, C. Jia, Y.-Y.Wang, N. Tang, X.-J.Yang, Q.-Z. Shi,Cryst.Growth Des.10 (2010) 2331.

[6] G. Wei, Y.-F.Shen, Y.-R.Li, X.-C. Huang, Inorg. Chem. 49 (2010) 9191.

[7] V. Balzani, A. Credi, M. Venturi, Molecular Devices and Machines, Wiley-VCH,Weinheim, 2003.

[8] M. Petty, Molecular Electronics: From Principles to Practice, Wiley, Chichester, 2008.

[9] S.H. Rahaman, R. Ghosh, G. Mostafa, B.K. Ghosh, Inorg. Chem. Commun. 8(2005) 700.

[10] S.H. Rahaman, D. Bose, R. Ghosh, G. Mostafa, H.-K.Fun, B.K. Ghosh, Struct.Chem. 18 (2007) 237.

[11] H. Chowdhury, S.H. Rahaman, S.K. Sarkar, H.-K.Fun, B.K. Ghosh, J. Mol. Struct.826 (2007) 170. 
[12] S. Das, B.N. Sarkar, K. Bhar, S. Chattopadhyay, H.-K. Fun, P. Mitra, B.K. Ghosh,Inorg. Chem. Commun. 13 (2010) 353.

[13] B.N. Sarkar, K. Bhar, S. Chattopadhyay, S. Das, P. Mitra, B.K. Ghosh, J. Mol.Struct.963 (2010) 35.

[14] V. Alexander, Chem. Rev. 95 (1995) 273.

[15] P.A. Vigato, S. Tamburini, L. Bertolo, Coord. Chem. Rev. 251 (2007) 1311.

[16] G. Wu, X.-F.Wang, T. Okamura, W.-Y. Sun, N. Ueyama, Inorg. Chem. 45 (2006)8523.

[17] A. Lan, L. Han, D. Yuan, F. Jiang, M. Hong, Inorg. Chem. Commun. 10 (2007) 993.

[18] T. Chattopadhyaay, A. Banerjee, K.S. Banu, E. Suresh, M. Netahji, G. Birarda, E.Zangrando, D. Das, Polyhedron 27 (2008) 2452.

[19] B. Hollo, Z.D. Tomic, P. Pogany, A. Kovacs, V.M. Leovac, K.M. Szecsenyci,Polyhedron 28 (2009) 3881.

[20] A.M. Golub, H. Kohler, V.V. Skopenko (Eds.), Chemistry of Pseudohalides,Elsevier, Amsterdam, 1986.

[21] D.A. Buckingham, Coord. Chem. Rev. 135-136 (1994) 587.

[22] J. Ribas, A. Escuer, M. Monfort, R. Vicente, R. Cortes, L. Lezama, T. Rojo, Coord.Chem. Rev. $193-195$ (1999) 1027.

[23] Y.-Q. Sun, D.-Z.Gao, W. Dong, D.-Z.Liao, C.-X. Zhang, Eur. J. Inorg. Chem. (2009)2825.

[24] T.K. Maji, G. Mostafa, S. Sain, J.S. Prasadc, N.R. Chaudhuri, Cryst. Eng. Commun.37 (2001) 1.

[25] X. Shi, G. Zhu, Q. Fang, G. Wu, G. Tian, R. Wang, D. Zhang, M. Xue, S. Qiu, Eur. J. Inorg. Chem. (2004) 185.

[26] C.-D. Wu, W. Lin, Inorg. Chem. 44 (2005) 1137.

[27] Y. Jin, P. Yoon, J. Seo, J.-E.Lee, S.T. Moon, J. Kim, S.W. Han, K.-M.Park, L.F. Lindoy, S.S. Lee, Dalton Trans. 4 (2005) 788.

[28] H. Zhang, X. Wang, K. Zhang, B.K. Teo, Coord. Chem. Rev. 183 (1999) 157.

[29] S.H. Rahaman, R. Ghosh, G. Mostafa, B.K. Ghosh, Inorg. Chem. Commun. 8 (2005) 700.

[30] V. Haber, I. Cisaova, J. Fabry, Polyhedron 22 (2003) 3451.

[31] G. M. Sheldrick, ActaCryst., (2008) A64, 112-122.

[32] G. M. Sheldrick, SHELXL 2013, University of Göttingen, Germany, (2013).

[33] K. Brandenburg, Diamond Version 2.0 Impact GbR, Bonn, Germany, (1998).

[34] A. Naito, S. Ganapathyet C.A. McDowell, J. Magn. Reson., 48 (1982) 367.

[35] M. Belhouchet, M. Bahri, J. M. Savariault, T. Mhiri, Spectrochim. Acta A 61 (2005) 387.

[36] N. L.Calve, F. Romain, M. H. Limage, A. Novak, J. Mol. Struct. 200 (1989) 131.

[37] S. Shanmuga Sundara Raj, H. K. Fun, P. S. Zhao, F. F. Jian, L. D. Lu, X. J. Yang, X.Wang, ActaCryst. C56 (2000) 742.

[38] B. Chenon, C. Sandorfy, Can. J. Chem. 36 (1958) 1181.

[39] K.Nakamoto, Infrared and Raman Spectra of Inorganic and Coordination Compounds, Wiley-Interscience, New York, 1986. 